\title{
EDTA-Dependent Pseudothrombocytopenia
}

\author{
EDTA-İlişkili Yalancı Trombositopeni
}

\author{
Ayşenur Bahadır, Erol Erduran, Beril Dilber, Nalan Üçüncü
}

Karadeniz Technical University, School of Medicine, Department of Pediatric Hematology, Trabzon, Turkey

Ethylenediaminetetraacetic acid-dependent pseudothrombocytopenia (EDTA-DP) occurs rarely, with an incidence rate of 0.09\%-0.21\%. EDTA-DP may lead to misdiagnosis since low platelet count may determine by outomated blood counter in which EDTA as anticoagulant is used $[1,2]$. It is diagnosed via microscopic detection of platelet aggregates in a peripheral blood smear. Additionally, in vitro clumping of the platelets occurs due to autoantibodies that develop against platelet surface antigens [1]. Although automatic blood analyzers are widely used, peripheral blood smear is the hematological gold standard for definitive diagnosis. When the thrombocyte number is low the morphology and appearance of platelets must be confirmed via a peripheral blood smear. As such, laboratory errors and excessive expenditure of time can be avoided.

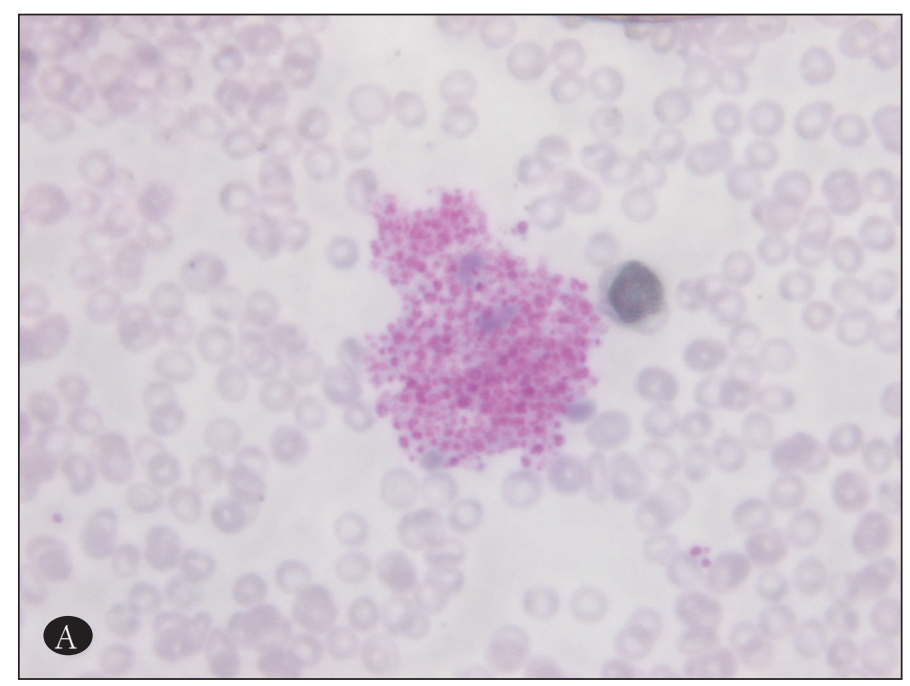

A 7-year old boy was referred to our hospital due to thrombocytopenia The patient's platelet count was determined by a different laboratory to be between $10 \times 10^{9} / \mathrm{L}$ and $15 \times 10^{9} / \mathrm{L}$. History of familial or acquired hemorrhagic disorders, lymphadenopathy, drug intake, blood transfusion, systemic disease, and recent viral infection was negative. Physical examination was normal. Laboratory findings were as follows: platelet count: $13 \times 10^{9} / \mathrm{L}$; hemoglobin: $12.2 \mathrm{~g} / \mathrm{dL}$; white blood cell count: $14,8 \times 10^{9} / \mathrm{L}$; mean platelet volume: $8.8 \mathrm{fL}$. Aggregation of platelets was observed via microscopic examination of the peripheral blood smear (Figure 1A and 1B). Direct Coombs' test, and cold agglutinin, serum immunoglobulins, antinuclear antibody, total protein, and lipid levels were normal. Using sodium citrate, the patient's platelet count was 249 x109/L (Figure 2).

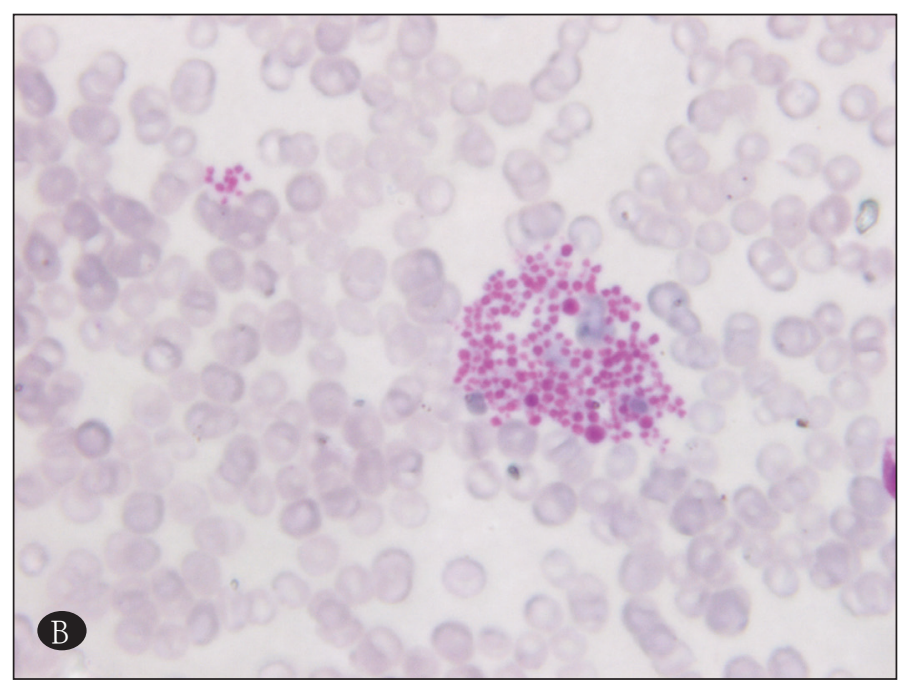

Figure 1A and 1B: Aggregation of platelets in the peripheral blood smear with EDTA (Wright-Giemsa, 100x).

\section{Address for Correspondence: Ayşenur BAHADIR, M.D.,}

Karadeniz Teknik Üniversitesi, Tıp Fakültesi, Pediatrik Hematoloji Bilim Dalı, Trabzon, Turkey

Phone: +90 4623775776 E-mail: aysenurkbr@yahoo.com

Received/Geliş tarihi : July 4, 2011

Accepted/Kabul tarihi : August 15, 2011 


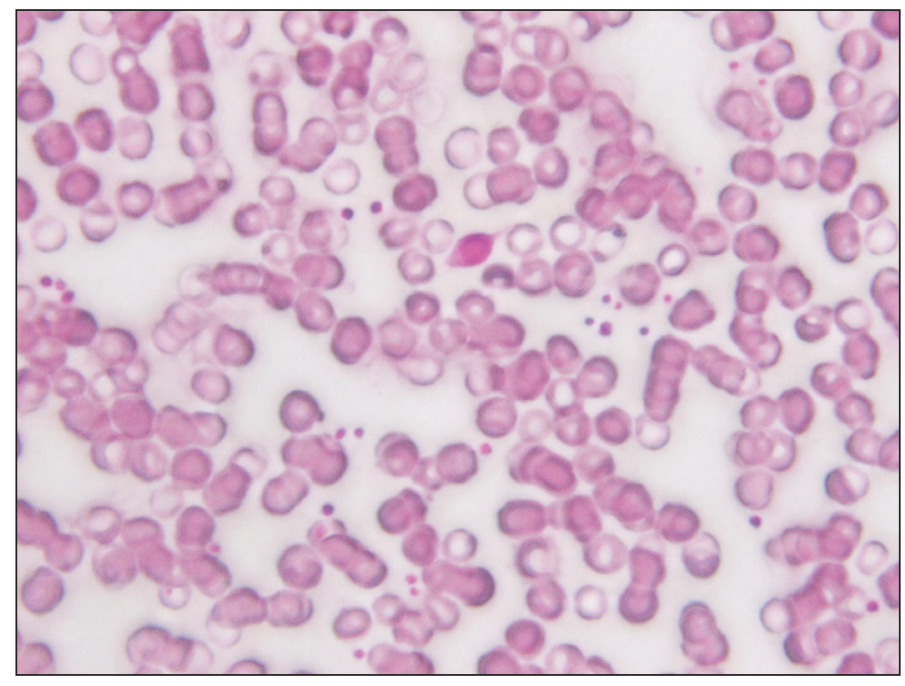

Figure 2: Normal peripheral blood smear with sodium citrate (Wright-Giemsa, 100x).

We considered that EDTA-DP induced platelet agglutination in vitro, resulting in the observed decrease in the platelet count, and therefore diagnosed the patients as EDTA-DP. The patient was not given any treatment. During 4 months of outpatient follow-up the patient's platelet count varied between 200 and $409 \times 10^{9} / \mathrm{L}$. Written informed consent was obtained.

EDTA-DP may be erroneously diagnosed due to a false low platelet count measured in an automated blood analyzer in which EDTA was used as anticoagulant. Aggrega- tion of platelets in EDTA-DP is prevented by other anticoagulants, such as sodium citrate or heparin [3]. The presented patient was referred to our clinic due to thrombocytopenia. The patient's peripheral blood smear had not been evaluated prior to presentation to our facility EDTADP was diagnosed when clustered platelets were separately seen on the peripheric blood smear in our hematology clinic. Nowadays, automatic blood count device has been used. But still, peripheric blood semear is the gold standart for hematologists for definitive diagnosis. When thrombocytopenia is detected, peripheric blood smear should be performed from the finger tip and examined to see whether or not it is a real or pseudothrombocytopenia.

\section{Conflict of Interest Statement}

None of the authors has any conflicts of interest, including specific financial interests, relationships, and/or affiliations, relevant to the subject matter or materials included.

\section{References}

1. Yoneyama A, Nakahara K. EDTA-dependent pseudothrombocytopenia-differentiation from true thrombocytopenia. Nippon Rinsho 2003; 61 (4): 569-574

2. Carrillo-Esper R, Contreras-Dominguez V. Pseudothrombocytopenia induced by ethylenediaminetetraacetic acid in burned patients. Cir Cir 2004; 72 (4): 335-338

3. Celkan T, Toptan H, Dogru O. Spurious thrombocytopenia. Turk Arch Ped 2009; 44 (2): 73-74

\section{Erratum}

Please kindly be informed that the units of laboratory measurements should be corrected in a recent article by Özkaya et al (TJH 2012;29:195-196), entitled "Carbamazepine -induced red blood cell aplasia: A case report", as follows: Red blood cell counts $\times 10^{12} \mathrm{~L}^{-1}$, white blood cell counts $\times 10^{9} \mathrm{~L}^{-1}$, platelet counts $\times 10^{9} \mathrm{~L}^{-1}$, serum iron level and total iron binding capasity $\mu \mathrm{g} \mathrm{dL^{-1 }}$. 